\title{
Importance of allochthonous resources in the diet of Astyanax aff. fasciatus (Osteichthyes: Characidae) in streams: a longitudinal approach
}

\author{
Marlene R. Silva ${ }^{1}$, Rosemara Fugi ${ }^{1,2}$, Natália Carniatto ${ }^{1,3}$ \& Maria Júlia M. Ganassin ${ }^{1}$ \\ ${ }^{I}$ Programa de Pós-Graduação em Ecologia de Ambientes Aquáticos Continentais (PEA) - Universidade \\ Estadual de Maringá, Av. Colombo 5790, Jardim Universitário, Bloco G-90, CEP 87020-900, Maringá, \\ Paraná,Brazil.e-mail: marleners@ibest.com.br(MRS); rosemarafugi@gmail.com (RF); \\ nati_carniatto@hotmail.com (NC) \\ ${ }^{2}$ Núcleo de Pesquisas em Limnologia, Ictiologia e Aquicultura (Nupélia) - Universidade Estadual de \\ Maringá, Av. Colombo 5790, Jardim Universitário, Bloco G-90, CEP 87020-900, Maringá, Paraná, Brazil. \\ e-mail:mjganassin@hotmail.com (MJMG) \\ ${ }^{3}$ Corresponding author: Natália Carniatto,e-mail: nati_carniatto@hotmail.com
}

SILVA, M.R., FUGI, R., CARNIATTO, N., GANASSIN, M.J.M. Importance of allochthonous resources in the diet of Astyanax aff. fasciatus (Osteichthyes: Characidae) in streams: a longitudinal approach. Biota Neotropica. 14(3): e20130016. http://dx.doi.org/10.1590/1676-06032014001613

\begin{abstract}
The aim of this investigation was to respond the following question: is the consumption of allochthonous resources by Astyanax aff. fasciatus influenced by the longitudinal gradient in streams? To respond this question we sampled fish in the headwater, middle and mouth stretches of four streams (Upper Paraná River basin). Samplings were carried out from July 2007 to June 2008 using electrical fishing. Fish were identified, measured and their stomach contents identified and quantified. Spatial variations (among longitudinal stretches) in the diet were summarized using a principal coordinate analysis (PCoA). Spatial differences in the diet were tested with a multiresponse permutation procedure (MRPP). Allochthonous resources had the highest percentage of the A. aff. fasciatus diet in all stretches; however, the increased importance of autochthonous resources in the fish diet in the stream mouths made these stretches to differ significantly from the middle and headwater ones. The ordination analysis separated the fish diet sampled in the stream mouth from the diet of most fish samples in the headwater and middle stretches. The results highlight the importance of allochthonous resources, mainly insects, in the diet of $A$. aff. fasciatus. However, the diet was affected by longitudinal gradient and followed the pattern described for these ecosystems, where fish depend basically of allochthonous material in the headwaters and the importance of these resources decrease along the longitudinal gradient.
\end{abstract}

Keywords: Fish, feeding resources, terrestrial subsidies, Pirapó River, Paraná River.

SILVA, M.R., FUGI, R., CARNIATTO, N., GANASSIN, M.J.M. Importância dos recursos alóctones na dieta de Astyanax aff. fasciatus (Osteichthyes: Characidae) em riachos: uma abordagem longitudinal. Biota Neotropica. 14(3): e20130016. http://dx.doi.org/10.1590/1676-06032014001613

Resumo: O objetivo deste estudo foi responder a seguinte pergunta: o consumo de recursos alóctones por Astyanax aff. fasciatus é influenciado pelo gradiente longitudinal dos riachos? Para responder esta questão, foram amostrados peixes na cabeceira, no meio e na foz de quatro riachos (bacia do alto Rio Paraná). As amostragens foram realizadas entre julho/2007 e junho/2008, utilizando-se pesca elétrica. Os peixes foram identificados, medidos e seus conteúdos estomacais identificados e quantificados. Variações espaciais (entre os trechos) na dieta foram sumarizadas através da análise de ordenação de coordenadas principais (PCoA). Diferenças espaciais na dieta foram testadas através do procedimento de permutação de multiresposta (MRPP). Recursos alimentares alóctones compuseram a maior parcela da dieta de $A$. aff. fasciatus em todos os trechos, porém, na foz dos riachos a dieta diferiu significativamente do meio e da cabeceira, sendo esta diferença causada pelo incremento de recursos autóctones na dieta na foz. A análise de ordenação mostrou a separação da dieta dos peixes amostrados na foz da dieta da maioria dos peixes amostrados na cabeceira e no meio. Estes resultados evidenciam a importância de recursos alóctones, principalmente insetos, na dieta de $A$. aff. fasciatus. No entanto, a dieta foi influenciada pelo gradiente longitudinal, seguindo o padrão descrito para estes ambientes, onde na cabeceira os peixes dependem primariamente de material alóctone, e ao longo do gradiente ocorre um decréscimo na importância destes recursos.

Palavras-chave: Peixes, recursos alimentares, subsídios terrestres, rio Pirapó, Rio Paraná. 


\section{Introduction}

Fish inhabiting streams depend on some environmental factors for the success of their ecological functions, such as the size of the stream and drainage basin (Oliveira \& Bennemann 2005), morphological characteristics of the environment, flow velocity, cover of riparian vegetation (Vannote et al. 1980, Ferreira \& Casatti 2006, Lorion \& Kennedy 2009), availability of autochthonous (in situ) and allochthonous food resources (ex situ) (Vannote et al. 1980, Polis et al. 1997, Lancaster et al. 2008, Lorion \& Kennedy 2009).

Streams and adjacent areas are ecosystems closely connected by the flow of matter and by the movement of organisms (Baxter et al. 2005), and this exchange allows the input of resources to aquatic ecosystem (Power et al. 2004, Lorion \& Kennedy 2009). Subsidies comprise the flow of energy biologically fixed and nutrients from an ecosystem to another, that is, allochthonous resources (Polis et al. 1997, Richardson et al. 2009), and the vegetation adjacent to rivers and streams potentially has a large impact on aquatic communities (Erös et al. 2012). Thus, as important as the high internal productivity of the aquatic ecosystem, which sustains consumer populations, are the subsidies coming from the interface of terrestrial habitats, which ensures the supply of food resources to local populations even in environments where primary productivity is low (Rose \& Polis 1998, Pace et al. 2004, Richardson et al. 2009). Subsidies as invertebrates can represent up to half of the energy in the diet of stream fish (Masson \& Macdonald 1982), indicating that in these environments the availability of prey induce higher consumption (Rezende \& Mazzoni, 2006), or the fishes have a preference for these organisms (Main \& Lyon 1988, Garman 1991). The importance of subsidies in the diet of stream fish has been frequently reported in tropical regions (Henry et al. 1994, Vitule et al. 2008, Wolff et al. 2009, Tófoli et al. 2010, Manna et al. 2012, Small et al. 2013).

The input of subsidies to lotic ecosystems is associated with a gradient of physical conditions and biotic adjustments, from the headwaters to the mouth (River Continuum Concept, sensu Vannote et al. 1980). The headwaters suffers greater influence from the riparian vegetation than the mouth, decreasing the autotrophic production due to shading of the water, and at the same time contributing to the input of allochthonous material (mainly plants and insects) (Vannote et al. 1980). In rivers and streams there is a remarkable longitudinal gradient of food resources dominant in the fish diet, and in headwaters regions fish depend primarily on allochthonous material, made up of terrestrial insects and plant debris (Lowe-McConnell 1975). Manna et al. (2012) observed that the diet of Astyanax taeniatus varied according to physical characteristics of the environment, showing a reduced amount of allochthonous resources (mostly plant debris) along the longitudinal gradient of the stream.

Species of the genus Astyanax are considered flexible in the use of food resources in streams, and have been described as opportunistic with high feeding plasticity (Wolff et al. 2009, Manna et al. 2012). However several studies have shown the predominance of allochthonous resources, especially insects and higher plants (leaves, fruits and seeds) in the diet of these fish in streams (Bennemann et al. 2005, Borba et al. 2008, Ferreira et al. 2011), even those with little vegetation cover (Borba et al. 2008). On the other hand, some species of this genus have also consumed predominantly autochthonous resources (Mazzoni \& Costa 2007, Mazzoni et al. 2010). According to Mazzoni et al. (2010) the almost absolute predominance of autochthonous items in the diet of Astyanax janeiroensis in closed sites of a coastal stream highlights the importance of internal processes in the maintenance of low order stream systems.

In this context, this study aimed to respond the following question: is the consumption of allochthonous resources by Astyanax aff. fasciatus (Cuvier, 1829) influenced by the longitudinal gradient in streams? To answer this question, fishes were sampled in rural streams belonging to the sub-basin of the Pirapó River, Upper Paraná River basin.

\section{Material and Methods}

\section{Study area}

This study was conducted in four low order rural streams (Água da Roseira, Remo, Romeira and Zaúna - Figure 1), belonging to the Pirapó River sub-basin, Upper Paraná River basin. This sub-basin is bounded by latitude $22^{\circ} 30$ 'and $23^{\circ} 30^{\prime}$ South and longitude $51^{\circ} 15^{\prime}$ and $52^{\circ} 15^{\prime}$ 'West, with a drainage area of approximately $5,076 \mathrm{~km}^{2}$ (Peruço 2004). Sampling was performed in three stretches of each stream: headwaters $(\mathrm{He})$, middle (Mi) and mouth (Mo) (Figure 1).

The Água da Roseira stream has steep banks, narrow bands of arboreal riparian vegetation $(\mathrm{He}=14.3 \mathrm{~km} ; \mathrm{Mi}=16.0 \mathrm{~km}$; Mo $=11.0 \mathrm{~km})$, drainage area of $867 \mathrm{~km}^{2}$ and is located at $23^{\circ} 20^{\prime} 56,30^{\prime}$ 'S - 51 ${ }^{\circ} 54 ' 52,31^{\prime \prime} \mathrm{W}$. The Remo stream has heterogeneous arboreal vegetation, alternating native and exotic species. The width of the vegetation along its banks is variable $(\mathrm{He}=54.0 \mathrm{~km} ; \mathrm{Mi}=19.0 \mathrm{~km} ; \mathrm{Mo}=15.0 \mathrm{~km})$, its drainage area is of $792 \mathrm{~km}^{2}$ and is located between coordinates $23^{\circ} 21^{\prime} 39,26^{\prime \prime} \mathrm{S}$ - $52^{\circ} 01^{\prime} 02,48^{\prime \prime} \mathrm{W}$. The Romeira stream has riparian vegetation with variable width along its steep banks $(\mathrm{He}=24.5 \mathrm{~km}$; $\mathrm{Mi}=$ $20.0 \mathrm{~km}$; Mo $=9.5 \mathrm{~km})$; its drainage area has $895 \mathrm{~km}^{2}$ and is located at $23^{\circ} 22^{\prime} 04,05^{\prime \prime} \mathrm{S}-51^{\circ} 58^{\prime} 43,50$ '” W. In the Zaúna stream the riparian vegetation is extensive along almost its entire course $(\mathrm{He}=27.0 \mathrm{~km} ; \mathrm{Mi}=30.3 \mathrm{~km}$; $\mathrm{Mo}=34.5 \mathrm{~km})$; it is the smallest stream among the studied streams, with drainage area of $297 \mathrm{~km}^{2}$, and is located at $23^{\circ} 23^{\prime} 47,36^{\prime}$ 'S - 51 ${ }^{\circ} 51^{\prime} 02,09^{\prime \prime} \mathrm{W}$. The headwaters and middle stretches were more structured considering the presence of trunks, branches and leaves in the bed, when compared to the mouth region. The width of the riparian vegetation was larger in the headwaters stretches, compared with the mouth, except for the Zaúna stream, where the vegetation width varied little between stretches.

\section{Sampling and data analysis}

Bimonthly samples were taken from July 2007 to June 2008, in three stretches of the streams, headwaters, middle and mouth, totaling 12 sampling sites. Samples were collected using electrofishing equipment (AC portable generator, $2.5 \mathrm{KW}, 400$ $\mathrm{V}, 2 \mathrm{~A}$ ), through three successive catches with constant unit effort over a segment of approximately 20-fold the average width of the stream bed (Lyons 1992), and the stretches were delimited by blocking nets with $2 \mathrm{~mm}$ between knots.

Fish caught were anesthetized with eugenol, preserved in $10 \%$ formalin and later identified, counted, measured (standard length), weighed (total weight) and eviscerated. Astyanax aff. fasciatus was not caught in enough number for analyses in the mouth of the Romeira stream. Voucher specimens were 


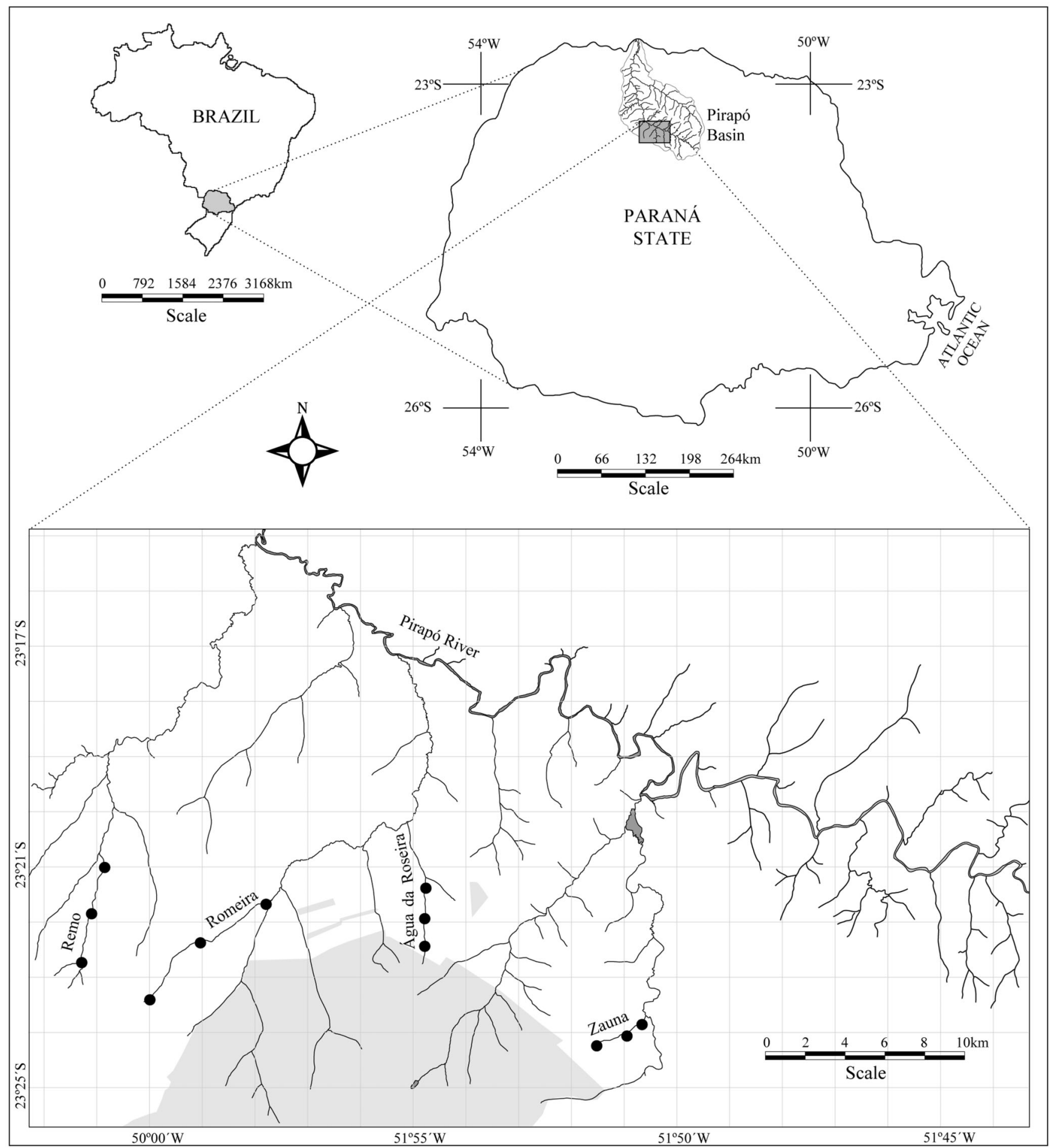

Figure 1. Location of streams in the sub-basin of the Pirapó River, Upper Paraná River basin, and sampling sites (•).

deposited in the Fish Collection of the Center for Research in Limnology, Ichthyology and Aquaculture - State University of Maringá (NUP 5580; NUP 6370). Stomachs with food were preserved in $70 \%$ alcohol and their contents were examined under stereoscopic and optical microscopes. Food items were identified and quantified by the volumetric method (Hyslop 1980), and the volume of each item was obtained using a graduated plate in which the volume is obtained in $\mathrm{mm}^{3}$ and thereafter converted into ml (Hellawel \& Abel 1971).
In order to verify the importance of allochthonous resources in the diet of $A$. aff. fasciatus, food items were grouped into autochthonous and allochthonous. To check the influence of the longitudinal gradient in the consumption of autochthonous and allochthonous resources, differences in diet composition between the headwaters, middle and the mouth stretches of each streams were tested using the nonparametric MRPP (Multi-Response Permutation Procedure - significance $\mathrm{p}<0.05)$, which tests multivariate differences between 
Silva M.R. et al.

Table 1. Diet composition (\% volume) of Astyanax aff. fasciatus in four streams of the sub-basin of the Pirapó River, Upper Paraná River basin $(\mathrm{He}=$ headwater; $\mathrm{Mi}=$ middle; $\mathrm{Mo}=$ mouth; value in parentheses represents the number of analyzed stomachs $)$. Aquatic invert.= other aquatic invertebrates; Terrestrial invert. $=$ other terrestrial invertebrates.

\begin{tabular}{|c|c|c|c|c|c|c|c|c|c|c|c|}
\hline \multirow[b]{2}{*}{ Resources/items } & \multicolumn{3}{|c|}{ Água Roseira } & \multicolumn{3}{|c|}{ Remo } & \multicolumn{2}{|c|}{ Romeira } & \multicolumn{3}{|c|}{ Zaúna } \\
\hline & $\begin{array}{c}\mathrm{He} \\
(13)\end{array}$ & $\begin{array}{c}\text { Mi } \\
(28)\end{array}$ & $\begin{array}{l}\text { Mo } \\
\text { (16) }\end{array}$ & $\begin{array}{l}\mathrm{He} \\
(25)\end{array}$ & $\begin{array}{c}\text { Mi } \\
(21)\end{array}$ & $\begin{array}{l}\text { Mo } \\
(48)\end{array}$ & $\begin{array}{l}\mathrm{He} \\
(5)\end{array}$ & $\begin{array}{c}\text { Mi } \\
(\mathbf{4 0})\end{array}$ & $\begin{array}{l}\mathrm{He} \\
(3)\end{array}$ & $\begin{array}{c}\text { Mi } \\
\text { (32) }\end{array}$ & $\begin{array}{l}\text { Mo } \\
\text { (14) }\end{array}$ \\
\hline Aquatic insects & 13.79 & 2.60 & 23.90 & 7.40 & 0.89 & 26.34 & 14.61 & 4.88 & 7.03 & 6.28 & 20.56 \\
\hline Diptera & 0.87 & 1.87 & 9.36 & 0.25 & 0.25 & 8.64 & 1.69 & 0.68 & 3.36 & 2.16 & 2.62 \\
\hline Trichoptera & 1.59 & 0.50 & 11.07 & 0.07 & 0.07 & 7.57 & 1.13 & 2.33 & 0.61 & 2.66 & 12.71 \\
\hline Coleoptera & & & & 0.08 & 0.06 & 2.04 & 0.28 & 0.36 & & 0.19 & 2.78 \\
\hline Ephemeroptera & & 0.13 & 2.60 & 1.68 & 0.42 & 3.77 & 0.56 & & 3.05 & 0.92 & 1.64 \\
\hline Hemiptera & & & & 0.00 & & & 10.93 & 0.96 & & 0.01 & 0.79 \\
\hline Odonata & 11.32 & 0.09 & 0.23 & 2.46 & 0.07 & 1.77 & & 0.52 & & 0.19 & \\
\hline Plecoptera & & & & 0.07 & & & & & & & \\
\hline Neuroptera & & & & 2.64 & & 2.53 & & & & & \\
\hline Aquatic invert. & 0.44 & 0.19 & 9.04 & 5.04 & 3.66 & 1.23 & 1.13 & 0.81 & 3.36 & 0.98 & 0.66 \\
\hline Amphipoda & & & & 3.93 & & 0.24 & 1.13 & & & & 0.31 \\
\hline Microcrustáceo & & & 0.63 & 0.03 & & 0.45 & & & 3.05 & 0.54 & \\
\hline Oligochaeta & 0.42 & 0.18 & 8.38 & 1.08 & 3.65 & 0.03 & & 0.81 & & 0.15 & 0.31 \\
\hline Tecameba & 0.01 & 0.01 & 0.02 & & & 0.50 & & & & 0.28 & 0.03 \\
\hline Bryozoa & & & & & & & & & 0.30 & & \\
\hline Detritus/sediment & 0.18 & 0.20 & 6.15 & 6.31 & & 6.22 & 0.28 & 0.35 & & & 0.03 \\
\hline Terrestrial insects & 54.01 & 83.11 & 32.97 & 29.99 & 75.41 & 42.52 & 76.88 & 51.93 & 86.54 & 69.41 & 40.89 \\
\hline Hymenoptera & 27.87 & 52.92 & 31.30 & 17.69 & 15.71 & 14.67 & 36.82 & 9.45 & 47.40 & 28.55 & 10.97 \\
\hline Coleoptera & 2.05 & 1.36 & 0.34 & 3.48 & 1.21 & 5.04 & 23.79 & 22.32 & & 11.94 & 15.45 \\
\hline Homoptera & 2.40 & 0.13 & & 1.35 & 1.08 & 3.73 & & 0.05 & & 1.93 & \\
\hline Lepidoptera & 5.90 & 28.01 & & 5.03 & 45.24 & 11.53 & 1.59 & 15.44 & 36.69 & 22.52 & 10.91 \\
\hline Diptera & & & 0.17 & 1.09 & 0.04 & 0.11 & 11.33 & 0.21 & & 0.59 & \\
\hline Hemiptera & 0.08 & 0.36 & & 0.04 & 0.72 & 0.02 & & 1.60 & & 1.15 & 2.54 \\
\hline Orthoptera & 14.83 & & & & 10.10 & 2.28 & 1.13 & 1.72 & & 1.93 & \\
\hline Trichoptera & & & & & 0.57 & & & 0.29 & & 0.19 & \\
\hline Thysanoptera & & 0.02 & & & & 0.10 & & & & & \\
\hline Isoptera & & & & & & 1.50 & & 0.14 & & & \\
\hline Dermaptera & & 0.01 & & & & & & & & & \\
\hline Remains & 0.85 & 0.27 & 1.15 & 1.29 & 0.69 & 3.51 & 2.26 & 0.67 & 2.44 & 0.57 & 1.00 \\
\hline Terrestrial invert. & 11.32 & 0.13 & & 0.36 & 0.46 & 1.66 & 1.13 & 0.81 & & 5.60 & 0.07 \\
\hline Aranea & 11.32 & 0.13 & & 0.36 & 0.46 & 0.64 & 1.13 & 0.08 & & 1.54 & 0.07 \\
\hline Isopoda & & & & & & 1.01 & & 0.73 & & 4.05 & \\
\hline Terrestrial plants & 20.24 & 13.74 & 27.91 & 50.87 & 19.56 & 22.01 & 5.94 & 41.19 & 3.05 & 17.70 & 37.75 \\
\hline
\end{tabular}

predefined groups (McCune \& Grace 2002). The null hypothesis tested is that there is no difference in diet composition between stretches of streams.

To summarized the patterns of longitudinal variation (headwaters, middle, and mouth) in the diet composition of A. aff. fasciatus we used a Principal Coordinates Analysis (PCoA) (Legendre \& Legendre 1998), applied to the diet data matrix, for each stream, controlling the longitudinal gradient (headwaters, middle and mouth). For this analysis, food items were grouped into: aquatic insects, other aquatic invertebrates, detritus/sediment, terrestrial insects, other terrestrial invertebrates and terrestrial plants (see Table 1 of Results), and these groups were referred to as food resources. This analysis was run in R Programming Environment using the Vegan package (The $R$ Project for Statistical Computing, http://www.r-project.org/).

Differences in diet composition, considering different food resources (Table 1), between the headwaters, middle and mouth of each stream, were tested by a MRPP (Multi-Response Permutation Procedure) as previously described. Analyses were run using the software PC-Ord 4.0 (McCune \& Mefford 2006).

\section{Results}

To describe the diet were analyzed the stomach content of 245 individuals of $A$. aff. fasciatus, whose standard length ranged between 2.0 and $10.0 \mathrm{~cm}$. The species showed varied diet, totaling 28 food items, grouped into six types of food resources (Table 1). Considering the origin of food resources, in general, allochthonous resources comprised the largest portion of the diet in all stretches of the four streams (Figure 2), but, significant differences were detected in relation to the longitudinal gradient (Table 2).

At the headwaters and middle stretches of the four streams sampled, allochthonous resources were dominant in the diet of $A$. aff. fasciatus, whereas in the mouth, although allochthonous resources also have been used most frequently, autochthonous resources represented a significant portion of the diet (Figure 2). Significant differences were registered in the composition of allochthonous and autochthonous resources in the diet of $A$. aff. fasciatus along the longitudinal gradient, with differences detected between the headwaters and mouth for two, of the 

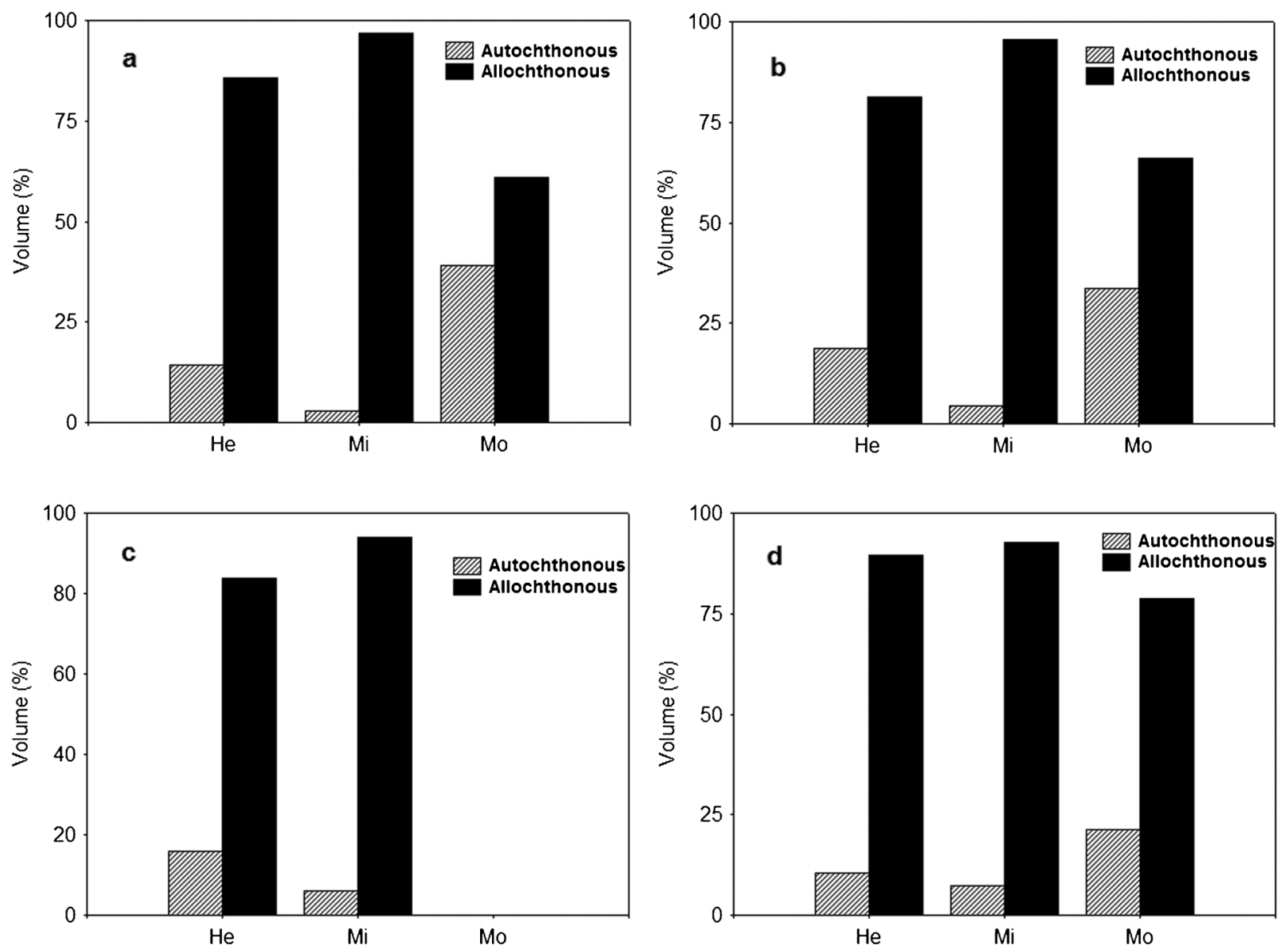

Figure 2. Percentage composition (volume) of autochthonous and allochthonous resources in the diet of Astyanax aff. fasciatus in four streams ( $a=$ Água da Roseira; $b=$ Remo; $c=$ Romeira; $d=$ Zaúna) of the sub-basin of the Pirapó River, Upper Paraná River basin (He= headwaters; $\mathrm{Mi}=$ middle; $\mathrm{Mo}=$ mouth).

three streams sampled in mouth (Table 2). In only one stream, the diet was similar. There were significant differences between the middle and mouth for all streams sampled in mouth, showing that the diet can vary a lot between these two stretches (Table 2). There were no significant differences in the

Table 2. Multi Response Permutation Procedure (MRPP) used to test differences in the composition of autochthonous and allochthonous items in the diet of Astyanax aff. fasciatus, along the longitudinal gradient $(\mathrm{He}=$ headwater; $\mathrm{Mi}=$ middle; $\mathrm{Mo}=$ mouth $)$ of four streams of the sub-basin of the Pirapó River, Upper Paraná River basin.

\begin{tabular}{lccc}
\hline Stream & & $\mathbf{A}$ & $\boldsymbol{p}$ \\
\hline Água da Roseira & $\mathrm{He} \times \mathrm{Mi}$ & 0.022 & 0.082 \\
& $\mathrm{He} \times \mathrm{Mo}$ & 0.044 & 0.037 \\
& $\mathrm{Mi} \times \mathrm{Mo}$ & 0.169 & $<0.001$ \\
& $\mathrm{He} \times \mathrm{Mi}$ & 0.008 & 0.192 \\
Remo & $\mathrm{He} \times \mathrm{Mo}$ & 0.141 & $<0.001$ \\
& $\mathrm{Mi} \times \mathrm{Mo}$ & 0.172 & $<0.001$ \\
& $\mathrm{He} \times \mathrm{Mi}$ & 0.004 & 0.301 \\
Romeira & $\mathrm{He} \times \mathrm{Mi}$ & 0.009 & 0.246 \\
Zaúna & $\mathrm{He} \times \mathrm{Mo}$ & 0.02 & 0.243 \\
& $\mathrm{Mi} \times \mathrm{Mo}$ & 0.159 & $<0.001$ \\
\hline
\end{tabular}

consumption of autochthonous and allochthonous resources between the headwaters and middle at the four streams sampled (Figure 2; Table 2).

The results of the ordination analysis indicated an important spatial separation in the diet of $A$. aff. fasciatus when considering the items grouped into food resources, and indicated that the longitudinal gradient was important in grouping the individuals analyzed (Figure 3). The first axis of the PCoA explained $82.2 \%$ of data variability, and so it was the only one analyzed. The variation revealed by this ordination showed the separation of the diet of fish sampled in the mouth stretches (positive scores) from the diet of most fish sampled at the headwaters and in middle stretches (negative scores). The food resource most positively correlated were aquatic insects, responsible for the grouping of individuals sampled in the mouth, and negatively, terrestrial insects, which grouped the majority of individuals caught in the headwaters and middle stretches of the streams (Figure 3).

Considering the food items grouped into food resources (Table 1) the diet composition of $A$. aff. fasciatus in the headwaters varied significantly from middle in two of the four streams sampled (Table 3). Between the headwaters and mouth differences were registered in only one stream. Significant differences were registered between the middle and mouth for all streams sampled in mouth. In general, in the headwaters and middle, terrestrial insects, was the most consumed resource 
Silva M.R. et al.

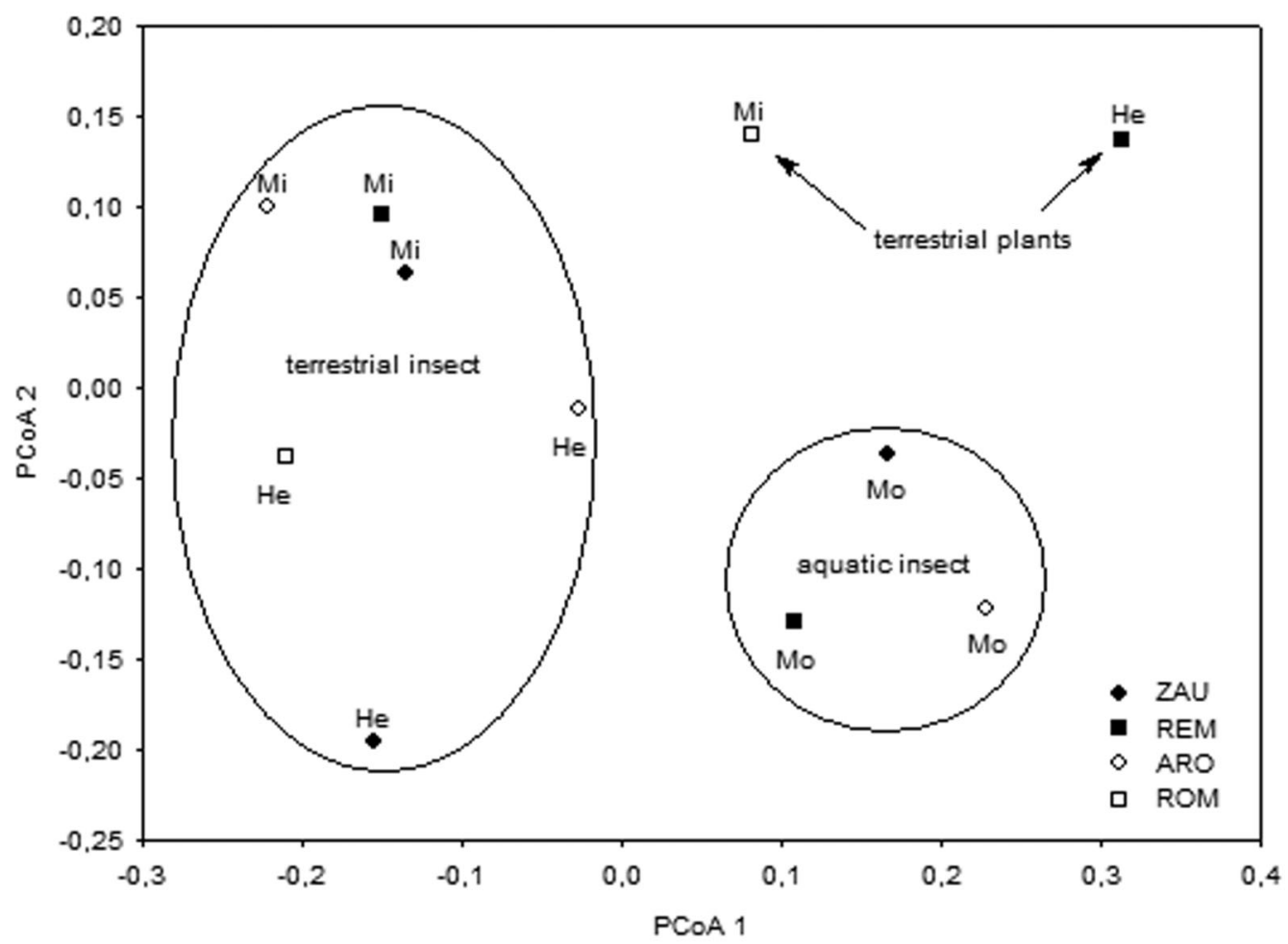

Figure 3. PCoA analysis of volumetric data of food resources in the diet of Astyanax aff. fasciatus in four streams (ARO= Água da Roseira; REM= Remo; ROM= Romeira; ZAU= Zaúna) of the sub-basin of the Pirapó River, Upper Paraná River basin $(\mathrm{He}=$ headwaters; $\mathrm{Mi}=$ middle; Mo= mouth).

(Table 1). Hymenoptera, Coleoptera and Diptera were important in the headwaters, and Coleoptera, Lepidoptera and Hymenoptera in the middle, in order of importance. Besides, in the headwaters, terrestrial plants and aquatic insects were also important in the diet (Table 3). In the mouth the diet of $A$. aff. fasciatus was composed of similar percentages of terrestrial insects, aquatic insects and terrestrial plants (Table 1).

Considering only main insect groups consumed by $A$. aff. fasciatus, it was observed an increasing trend of aquatic insects (Diptera and Trichoptera) in the diet in the mouth stretch (Figure 4). Hymenoptera was the most consumed terrestrial

Table 3. Multi Response Permutation Procedure (MRPP) used to test differences in the composition of items in the diet of Astyanax aff. fasciatus, along the longitudinal gradient $(\mathrm{He}=$ headwater; $\mathrm{Mi}=$ middle; Mo= mouth) of four streams of the sub-basin of the Pirapó River, Upper Paraná River basin.

\begin{tabular}{lccc}
\hline Stream & & $\mathbf{A}$ & $\boldsymbol{P}$ \\
\hline Água da Roseira & $\mathrm{He} \times \mathrm{Mi}$ & 0.03 & 0.032 \\
& $\mathrm{He} \times \mathrm{Mo}$ & 0.032 & 0.065 \\
& $\mathrm{Mi} \times \mathrm{Mo}$ & 0.051 & $<0.001$ \\
& $\mathrm{He} \times \mathrm{Mi}$ & 0.047 & 0.006 \\
Remo & $\mathrm{He} \times \mathrm{Mo}$ & 0.147 & $<0.001$ \\
& $\mathrm{Mi} \times \mathrm{Mo}$ & 0.148 & $<0.001$ \\
& $\mathrm{He} \times \mathrm{Mi}$ & 0.008 & 0.23 \\
Romeira & $\mathrm{He} \times \mathrm{Mi}$ & 0.011 & 0.068 \\
Zaúna & $\mathrm{He} \times \mathrm{Mo}$ & 0.025 & 0.22 \\
& $\mathrm{Mi} \times \mathrm{Mo}$ & 0.087 & $<0.001$ \\
\hline
\end{tabular}

insect in the headwaters of all streams, followed by Lepidoptera in the Zaúna stream, and Coleoptera in the Romeira stream, while aquatic insects were insignificant in this stretches (Figure 4a). In the middle stretch, terrestrial insects also predominated in all streams, with Hymenoptera being more consumed in Água da Roseira and Zaúna streams, Coleoptera in the Romeira, and Lepidoptera in the Remo stream, whereas aquatic insects were little consumed (Figure $4 \mathrm{~b}$ ). In the mouth stretch, aquatic Diptera and Trichoptera showed a relevant increment in the diet of $A$. aff. fasciatus, reaching percentages similar to those of terrestrial insects, except for Hymenoptera in the Água da Roseira stream (Figure 4c).

\section{Discussion}

Our results showed that $A$. aff. fasciatus consumed a wide range of food items and there was a predominance of allochthonous resources in the diet, particularly insects and plants, along the longitudinal gradient. Several studies in streams, involving the diet of fish fauna, reveal the importance of allochthonous subsidies to many species (Esteves \& Aranha 1999, Lowe-McConnell 1999, Casatti 2002, Silva et al. 2012), especially for the genus Astyanax (Bennemann et al. 2005, Borba et al. 2008, Wolff et al. 2009, Ferreira et al. 2011, Ferreira et al. 2012, Manna et al. 2012). Specifically for $A$. aff. fasciatus it was reported a high consumption of terrestrial plants and insect remains in streams of the Atlantic forest (Villela et al. 2002, Wolff et al. 2009).

Nevertheless, the substantial consumption of allochthonous resources in the headwaters and middle stretches and the expressive consumption of aquatic insects in the mouth evidenced the influence of the longitudinal gradient in the diet of $A$. aff. fasciatus. These differences were caused by the 

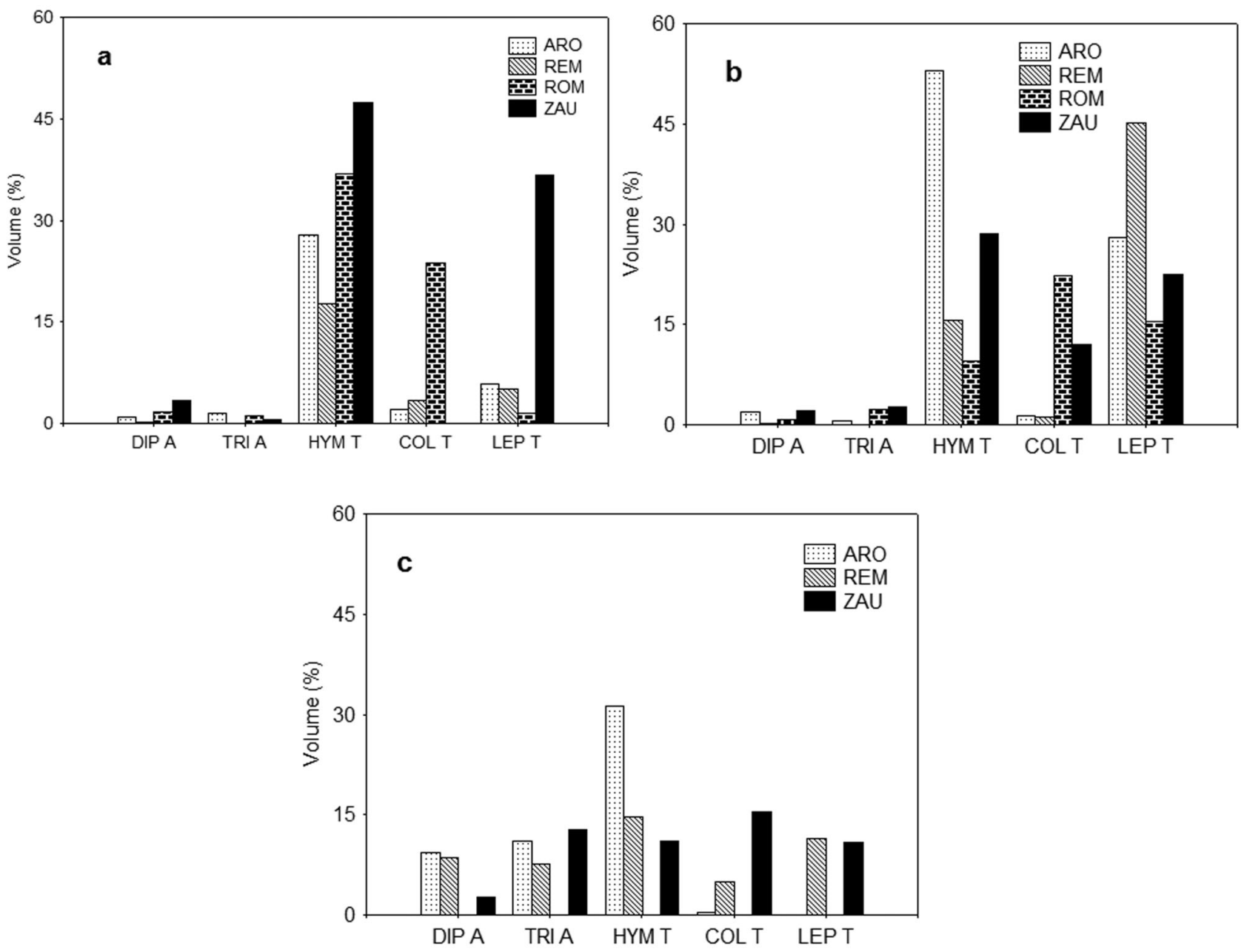

Figure 4. Participation (\% volume) of main insect groups in the diet of Astyanax aff. fasciatus in four streams (ARO=Água da Roseira; REM= Remo; ROM= Romeira; ZAU= Zaúna) of the sub-basin of the Pirapó River, Upper Paraná River basin ( $a=$ headwaters; $b=$ middle, $c=$ mouth; DIP A= aquatic Diptera; TRI A= aquatic Trichoptera; HYM T= terrestrial Hymenoptera; COL T= terrestrial Coleoptera; LEP T= terrestrial Lepidoptera).

increase of autochthonous resources, mainly aquatic insects represented by immature Trichoptera and Diptera, and may be related to factors such as the presence of riparian vegetation along the gradient, greater internal structure of the bed at the headwaters and middle, and larger width of the channel in the mouth stretch. Vannote et al. (1980) stated that in lotic ecosystems, from the headwaters to the mouth, one can find a continuous gradient of physical and biological conditions. The headwaters region is influenced by the surrounding vegetation, which contributes with allochthonous material (plant material and terrestrial insects), as the stream enlarges, decreases the importance of importing terrestrial organic matter. The riparian vegetation is well documented in the literature as a major supplier of food for aquatic organisms (Vannote et al. 1980, Polis et al. 1997, Baxter et al. 2005, Manna et al. 2012, Silva et al. 2012), in turn controlling the flow of nutrients. The shading produced by riparian vegetation limits the autotrophic production, and fish depend on resources from the slopes for feeding (Lowe-McConnell 1999). Moreover, Polis et al. (1997) considered the spatial scale, emphasizing the ration of edge to the water body (i.e. perimeter-to-area - P/A), which declines from the headwaters towards the mouth, with a corresponding decline in the relative importance of local allochthonous inputs.
In this context, the internal structure (trunk, branches and leaves) of the headwaters and middle stretches increases the environmental heterogeneity, increases the substrate area for aquatic invertebrates, creating shelters (Wohl et al. 1995), which probably makes it difficult the capture of these organisms by fish. For A. taeniatus, Manna et al. (2012) demonstrated a reduction in the consumption of allochthonous resources, especially plant debris, and an increase for an aquatic Curculionidae larvae (Coleoptera) along the gradient of the stream.

Therefore in streams examined, the separation of the diet of fish sampled at the mouth section from the diet of most fish sampled at the headwaters and middle stretches is mainly the consequence of the consumption of aquatic insects, responsible for the grouping of individuals sampled at the mouth, and thus influenced by the longitudinal gradient.

Our results allow inferring the preference of $A$. aff. fasciatus for certain insect groups, e.g., Hymenoptera, corroborating studies that claim that this species swims at mid-water level and collect particles dragged by the flow (Casatti et al. 2001, Casatti 2002). Therefore, it is expected a higher consumption of organisms that fall into the water body, such as invertebrates, especially some species of ants wingless that walk on the 
branches and accidentally fall into the water, or the consumption of floating particles. Esteves \& Aranha (1999) highlight the importance of the drift material in fish feeding, and the relationship between the drift of invertebrates and feeding as a key aspect to the understanding of factors that regulate the production of fishes in streams. Rezende \& Mazzoni (2006) also highlighted the relationship between the consumption of Hymenoptera by a Characidae with its availability in the environment. In this way, the headwaters of the streams in the present study represented the most favorable region because the internal structure was greater, with lower current flow and perimeter-to-area ratio. Even in the headwaters and middle sections, where terrestrial insects dominated, it was possible to verify the influence of the longitudinal gradient when considering the groups of insects; Lepidoptera for example was particularly more consumed in the middle section. In the mouth, these variables presented an opposite trend, leading $A$. aff. fasciatus to consume more aquatic insects with benthic habit, such as larvae of Diptera and Trichoptera. In the latter case, it is believed that these macroinvertebrates are abundant in these stretches, and are dragged from the substrate by the current, facilitating the capture by $A$. aff. fasciatus. Uieda \& Ramos (2007) point out several factors that influence the distribution of aquatic organisms, including the current velocity and substrate type. Meantime, some groups of insects have adaptations to withstand the current flow, such as attachment by adhesive structures, claws and flattened shape (Bennett \& Humphries 1974), which permit them to inhabit areas with pronounced current, as verified by Uieda \& Ramos (2007) who found twice aquatic insects in areas of higher water velocity compared with sites with lower velocity in a Brazilian stream.

Although $A$. aff. fasciatus has flexible feeding habit according to the availability of resources (Vilella et al. 2002, Wolff et al. 2009, Manna et al. 2012), the results demonstrated that it was predominantly sustained by terrestrial food resources, indicating the importance of the riparian vegetation in these aquatic environments. Researches claim that riparian vegetation is of fundamental importance to streams (Pusey \& Arthington 2003, Abilhoa et al. 2008), and its removal causes serious impacts on the integrity of fish communities in tropical streams that depend on allochthonous resources (Angermeier \& Karr 1983, Bojsen \& Barriga 2002), like that of $A$. aff. fasciatus. With the expansion of agricultural activities the riparian vegetation of streams in rural areas has been compromised, so in addition to the importance of the longitudinal gradient for the supply of terrestrial resources it is expected that their input and availability for the fish to be more pronounced in streams with greater vegetation cover (Rezende \& Mazzoni 2006). Borba et al. (2008) evaluated the diet of Astyanax asuncionenses in four streams with different degrees of riparian vegetation preservation and verified that even where vegetation was scarce, the species consumed predominantly allochthonous resources, pointing out that despite the high degradation of the vegetation, the species still depends on these resources.

Although allochthonous resources have been essential in the diet of $A$. aff. fasciatus from the headwaters to the mouth, the longitudinal gradient can also be considered important to explain consistent patterns of import, transport, use and storage of organic matter (Uieda \& Kikuchi 1995) available for consumption to fish communities (Power 1983). This pattern in the supply of food resources can influence directly the presence of some species that have their optimal distribution coinciding with the degree of preservation of the habitat or specific impacts (Casatti et al. 2006). Thus the response of $A$. aff. fasciatus to the longitudinal gradient of the studied streams is positive to the diet, emphasizing the importance of the riparian vegetation for the maintenance of this species in these ecosystems.

\section{Acknowledgments}

We thank CS Pavanelli for fish identification; RM Tófoli and GHZ Alves for helping with the stomach contains. MR Silva and N Carniatto acknowledge the Brazilian Council of Research (Capes - CNPq) for providing grants.

\section{References}

ABILHOA, V., DUBOC, L.F. \& AZEVEDO-FILHO, D.P. 2008. A comunidade de peixes de um riacho de floresta com Araucária, alto rio Iguaçu, sul do Brasil. Rev. Bras. Zool. 25(2): 238-246, doi: http://dx.doi.org/10.1590/S0101-81752008000200012

ANGERMEIER, L.P. \& KARR, J.R. 1983. Fish communities along environmental gradients in a system of tropical streams. Environ. Biol. Fish. 9(2):117-135, doi: http://dx.doi.org/10.1007/BF00690857

BAXTER, C.V., FAUSCH, K.D. \& SAUNDERS, W.C. 2005. Tangled webs: reciprocal flows of invertebrate prey link streams and riparian zones. Freshwater Biol. 50: 201-220, doi: http:// dx.doi.org/10.1111/j.1365-2427.2004.01328.x

BENNEMANN, S.T., GEALH, A.M., ORSI, M.L. \& SOUZA, L.M. 2005. Ocorrência e ecologia trófica de quatro espécies de Astyanax (Characidae) em diferentes rios da bacia do rio Tibagi, Paraná, Brasil. Iheringia, Ser. Zool. 95(3): 247-254, doi: http://dx.doi.org/ 10.1590/S0073-47212005000300004

BENNETT, D.P. \& HUMPHRIES, D.A. 1974. Introducción a la ecologia de campo. H. Blume, Madrid.

BOJSEN, B.H. \& BARRIGA, R. 2002. Effects of deforestation on fish community structure in Ecuadorian Amazon streams. Freshwater Biol. 47(11): 2246-2260, doi: http://dx.doi.org/10.1046/j.13652427.2002.00956.x

BORBA, C.S., FUGI, R., AGOSTINHO, A.A. \& NOVAKOWSKI, G.C. 2008. Dieta de Astyanax asuncionensis (Characiformes, Characidae), em riachos da bacia do rio Cuiabá, Estado do Mato Grosso. Acta Sci. Biol. Scien. 30(1): 39-45.

CASATTI, L. 2002. Alimentação dos peixes em um riacho do Parque Estadual Morro do Diabo, bacia do Alto Paraná, sudeste do Brasil. Biota Neotrop. 2(2): http://www.biotaneotropica.org.br/v2n2/pt/ abstract?article+BN02502022002 (último acesso em 05/07/2013), doi: http://dx.doi.org/10.1590/S1676-06032002000200012

CASATTI, L., LANGEANI, F. \& CASTRO, R.M.C. 2001. Peixes de riacho do Parque Estadual Morro do Diabo, bacia do alto rio Paraná, SP. Biota Neotrop. 1(1): http://www.biotaneotropica.org. br/v1n12/pt/abstract?inventory+BN00201122001 (último acesso em 07/07/2013)

CASATTI, L., LANGEANI, F., SILVA, A.M. \& CASTRO, R.M.C. 2006. Stream fish, water and habitat quality in a pasture dominated basin, Southeastern Brazil. Braz. J. Biol. 66(2B): 681-696, doi: http://dx.doi.org/10.1590/S1519-69842006000400012

ERÖS T., GUSTAFSSON, P., GREENBERG, L.A. \& BERGMAN, E. 2012. Forest-stream linkages: effects of terrestrial invertebrate input and light on diet and growth of brown trout (Salmo trutta) in a boreal forest stream. Plos One 7(5):1-11, doi: http://dx.doi.org/ 10.1371/journal.pone.0036462

ESTEVES, K.E. \& ARANHA, M.R. 1999. Ecologia trófica de peixes de riachos. In Ecologia de peixes de riachos (Caramashi, E.P., Mazzoni R. \& Peres-Neto, P.R. eds.). Série Oecologia Brasiliensis, Vol. VII, PPGE-UFRJ, Rio de Janeiro, Brasil, p.157-182

FERREIRA, A., GERHARD, P. \& CYRINO, J.E.P. 2012. Diet of Astyanax paranae (Characidae) in streams with different riparian land covers in the Passa-Cinco River basin, Southeastern Brazil. 
Iheringia, Ser. Zool. 102(1): 80-87, doi: http://dx.doi.org/10.1590/ S0073-47212012000100011

FERREIRA, A., PAULA, F.R., FERRAZ, S.F.B., GERHARD, P., KASHIWAQUI, E.A.L., CYRINO, J.E.P. \& MARTINELLI, L.A. 2011. Riparian coverage affects diets of characids in neotropical streams. Ecol. Freshw. Fish 21(1):12-22, doi: http:// dx.doi.org/10.1111/j.1600-0633.2011.00518.x

FERREIRA, C.P. \& CASATTI, L. 2006. Influência da estrutura do hábitat sobre a ictiofauna de um riacho em uma micro-bacia de pastagem, São Paulo, Brasil. Rev. Bras. Zool. 23(3): 642-651, doi: http://dx.doi.org/10.1590/S0101-81752006000300006

GARMAN, G.C. 1991. Use of terrestrial arthropod prey by a streamdwelling cyprinid fish. Environ. Biol. Fish. 30(3): 325-331, doi: http://dx.doi.org/10.1007/BF02028848

HELLAWEL, J.M. \& ABEL R.A. 1971. A rapid volumetric method for the analysis of the food of fishes. J. Fish Biol. 3: 29-37, doi: http://dx.doi.org/10.1111/j.1095-8649.1971.tb05903.x

HENRY, R., UIEDA, V.S., AFONSO, A.A.O. \& KIKUCHI, R.M. 1994. Input of allochthonous matter and structure of fauna in a Brazilian headstream. SIL 25(3): 1866-1870.

HYSLOP, E.J. 1980. Stomach contents analysis - a review of methods and their applications. J. Fish Biol. 17: 411-429, doi: http:// dx.doi.org/10.1111/j.1095-8649.1980.tb02775.x

LANCASTER, J., DOBSON, M., MAGANA, A.M., ARNOLD, M. \& MATHOOKO, J.M. 2008. An unusual trophic subsidy and species dominance in a tropical stream. Ecology 89(8): 2325-2334.

LEGENDRE P. \& LEGENDRE, L. 1998. Numerical ecology. 2 ed. Amsterdam: Elsevier Science.

LORION, C.M. \& KENNEDY, B.P. 2009. Riparian forest buffers mitigate the effects of deforestation on fish assemblages in tropical headwater streams. Ecol. Appl. 19(2): 468-479, doi: http:// dx.doi.org/10.1890/08-0050.1

LOWE-McCONNEL, R.H. 1975. Fish communities in tropical freshwaters. Their distribution, ecology and evolution. Longman, London.

LOWE-McCONNELL, R.H. 1999. Estudos ecológicos de comunidades de peixes tropicais. Tradução: A.E.A.M. Vazzoler, A.A. Agostinho. \& P.T.M. Cunningham. EDUSP, São Paulo. Título original em inglês: Ecological studies in tropical fish communities.

LYONS, J. 1992. The length of stream to sample with a towed electrofishing unit when fish species richness is estimated. N. Am. J. Fish. Manage. 12(1):198-201, doi: http://dx.doi.org/10.1577/15488675(1992)012<0198:TLOSTS $>2.3$.CO;2

MAIN, M.R. \& LYON, G.L. 1988. Contribution of terrestrial prey to the diet of banded kokopu (Galaxias fasciatus Gray) (Pisces: Galaxiidae) in South Westland, New Zealand. SIL 23:1785-1789.

MANNA, L.R., REZENDE, C.F. \& MAZZONI, R. 2012. Plasticity in the diet of Astyanax taeniatus in a coastal stream from South-East Brazil. Braz. J. Biol. 72(4): 919-928, doi: http://dx.doi.org/10.1590/ S1519-69842012000500020

MASSON, C.F \& MACDONALD, S.M. 1982. The input of terrestrial invertebrates from tree canopies to a stream. Freshwater Biol. 12(4): 305-311, doi: http://dx.doi.org/10.1111/j.1365-2427.1982.tb00624.x

MAZZONI, R. \& COSTA, L.D.S. 2007. Feeding ecology of streamdwelling fishes from a coastal stream in the Southeast of Brazil. Braz. Arch. Biol. Techn. 50(4): 627-635, doi: http://dx.doi.org/ 10.1590/S1516-89132007000400008

MAZZONI, R., NERY, L.L. \& IGLESIAS-RIOS, R. 2010. Ecologia e ontogenia da alimentação de Astyanax janeiroensis (Osteichthyes, Characidae) de um riacho costeiro do Sudeste do Brasil. Biota Neotrop. 10(3): http://www.biotaneotropica.org.br/v10n3/en/ abstract?article +bn01010032010 (último acesso em 07/07/2013), doi: http://dx.doi.org/10.1590/S1676-06032010000300005

McCUNE, B. \& GRACE, J.B. 2002. Analysis of ecological communities. Gleneden Beach, Oregon.

McCUNE, B., MEFFORD, M.J. 2006. PC-ORD, version 5.0, Multivariate analysis of ecological data. MjM Solfware Desing, Gleneden Beach, Oregon.
OLIVEIRA, D.C. \& BENNEMANN, S.T. 2005. Ictiofauna, recursos alimentares e relações com as interferências antrópicas em um riacho urbano no sul do Brasil. Biota Neotrop. 1(1): http://www. biotaneotropica.org.br/v5n1/pt/abstract?article+BN02905012005 (último acesso em 07/07/2013)

PERUÇO, J.D. 2004. Identificação das principais fontes poluidoras de afluentes da bacia do alto rio Pirapó. Dissertação Mestrado, Universidade Estadual de Maringá, Maringá.

PACE, M.L., COLE, J.J., CARPENTER, S.R., KITCHELL, J.F., HODGSON, J.R., VAN DE BOGERT, M.C, BADE, D.L, KRITZBERG, E.S \& BASTVIKEN, D. 2004. Whole-lake carbon13 additions reveal terrestrial support of aquatic food webs. Nature 427: 240-243, doi: http://dx.doi.org/10.1038/nature02227

POLIS, G.A., ANDERSON, W.B. \& HOLT, R.D. 1997. Toward an integration of landscape and food web ecology: the dynamics of spatially subsidized food webs. Annu. Rev. Ecol. Syst. 28: 289-316, doi: http://dx.doi.org/10.1146/annurev.ecolsys.28.1.289

POWER, M.E., RAINEY, W.E., PARKER, M.S., SABO, J.L., SMYTH, A., KHANDWALA, S., FINLAY, J.C., MCNEELY, F.C., MARSEE, K. \& ANDERSON, C. 2004. River to watershed subsidies in an old-growth conifer forest. In Food Webs at the Landscape Level. (G.A. Polis M.E. Power\& G.R. Huxe eds.). The University of Chicago Press, Chicago, p. 217-240 .

POWER, M.E. 1983. Grazing responses of tropical freshwater fishes to different scales of variation in their food. Environ. Biol. Fish. 9(2):103-115, doi: http://dx.doi.org/10.1007/BF00690856

PUSEY, B.J. \& ARTHINGTON, A.H. 2003. Importance of the riparian zone to the conservation and management of freshwater fish: a review. Mar. Freshwater Res. 54:1-16, doi: http://dx.doi.org/ 10.1071/MF02041

REZENDE, C.F. \& MAZZONI, R. 2006. Disponibilidade e uso de recursos alóctones por Bryconamerius microcephalus (Miranda-Ribeiro) (Actinopterygii, Characidae), no córrego Andorinha, Ilha Grande, Rio de Janeiro, Brasil. Rev. Bras. Zool. 23(1): 218-222, doi: http://dx.doi.org/10.1590/S010181752006000100014

RICHARDSON, J.S., ZHANG, Y. \& MARCZAK, L.B. 2009. Resource subsidies across the land-freshwater interface and responses in recipient communities. River Res. Appl. Published online in Wiley InterScience $<$ www.interscience.wiley.com $>$.

ROSE, M.D. \& POLIS, G.E. 1998. The distribution and abundance of coyotes: the effects of allochthonous food subsidies from the sea. Ecology 79(3): 998-1007.

SILVA, J.C., DELARIVA, R.L. \& BONATO, K.O. 2012. Foodresource partitioning among fish species from a first-order stream in northwestern Paraná, Brazil. Neotrop. Ichthyol. 10(2): 389-399, doi: http://dx.doi.org/10.1590/S1679-62252012005000008

SMALL, G.E., TORRES, P.J., SCHWEIZER, L.M., DUFF, J.H. \& PRINGLE, C.M. 2013. Importance of terrestrial arthropods as subsidies in lowland neotropical rain Forest. Biotropica 45(1): 80-87.

TÓFOLI, R.M., HAHN, N.S., ZAIA, G.A. \& NOVAKOWSKI, G.C. 2010. Uso do alimento por duas espécies simpátricas de Moenkhausia (Characiformes, Characidae) em um riacho neotropical do Brasil. Iheringia, Ser. Zool. 100: 201-206, doi: http:// dx.doi.org/10.1590/S0073-47212010000300003

UIEDA, V.S. \& KIKUCHI, R.M. 1995. Entrada de material alóctone (detritos vegetais e invertebrados terrestres) num pequeno curso de água corrente na Cuesta de Botucatu, São Paulo. Acta Limn. Bras. 7: $105-114$

UIEDA, V.S. \& RAMOS, L.H.B. 2007. Distribuição espacial da comunidade de macroinvertebrados bentônicos de um riacho tropical (Sudeste do Brasil). Bioikos 21(1): 3-9.

VANNOTE, R.L., MINSHALL, G.W., CUMMINS, K.W., SEDELL, J.R. \& CUSHING, C. 1980. The river continuum concept. Can. J. Fish. Aquat. Sci. 37: 130-137, doi: http://dx.doi.org/ $10.1139 / \mathrm{f} 80-017$ 
VILELLA, F.S., BECKER, F.G. \& HARTZ, S.M. 2002. Diet of Astyanax species (Teleostei, Characidae) in an Atlantic Foresta River in Southern Brazil. Braz. Arch. Biol. Techn. 45(2): 223-232, doi: http://dx.doi.org/10.1590/S1516-89132002000200015

VITULE, J.R.S., BRAGA, M.R. \& ARANHA, J.M.R. 2008 Ontogenetic, spatial and temporal variations in the feeding ecology of Deuterodon langei Travassos, 1957 (Teleostei: Characidae) in a Neotropical stream from the Atlantic rainforest, Southern Brazil. Neotrop. Ichthyol. 6(2): 211-222, doi: http://dx.doi.org/10.1590/S1679-62252008000200008
WOHL, D.L., WALLACE, J.B. \& MEYER, J.L. 1995. Benthic macroinvertebrate community structure, function and production with respect to habitat type, reach and drainage basin in the southern Appalachian (U.S.A). Freshwater biol. 34(3): 447-464, doi: http://dx.doi.org/10.1111/j.1365-2427.1995.tb00902.x

WOLFF, L.L., ABILHOA, V., RIOS, F.S. \& DONATTI, L. 2009. Spatial, seasonal and ontogenetic variation in the diet of Astyanax aff. fasciatus (Ostariophysi: Characidae) in na Atlantic Forest river, Southern Brazil. Neotrop. Ichthyol. 7(2): 257-266. 